\title{
Parametric Insurance as Innovative Development Factor of the Agricultural Sector of Economy
}

\author{
Olena Prokopchuk ${ }^{1}$, Ihor Prokopchuk², Grzegorz Mentel ${ }^{3}$, Yuriy Bilan ${ }^{4}$ \\ ${ }^{1}$ Department of Finances, Banking and Insurance, Faculty of Economics and Entrepreneurship, Uman \\ National University of Horticulture, Ukraine \\ 2 Department of Agrochemistry and Soil Science, Faculty of Agronomy, Uman National University \\ of Horticulture, Ukraine \\ ${ }^{3}$ Department of Quantitative Methods, Faculty of Management, Rzeszow University of Technology, Poland \\ ${ }^{4}$ Centre of Applied Economic Research, Tomas Bata University in Zlin, Czech Republic
}

\begin{abstract}
In the article a parallel between the classical and parametric scheme of agricultural risk insurance is conducted. The application aspects of parametric (index) schemes of insurance with emphasis on the use of weather index insurance products are examined, their advantages and disadvantages are considered.

This research examined the applicability along with simple weather index insurance products combined, that can consider and put together a few parameters simultaneously and thus neutralize the impact of the whole weather risks at regional level. The authors demonstrated the feasibility of using the proposed combination of weather index $\left(\mathrm{C}_{\mathrm{i}}\right)$ - a special indicator which characterize the impact of weather risk combitation intensity, measured by certain parameters (heat, cold $\rightarrow$ temperature; air humidification $\rightarrow$ relative humidity; drought $\rightarrow$ precipitation) on the grain maize yield in definite growth stages (flowering and grain filling). On the basis of research, the detail mechanism proposed by the authors of the combined weather index (Ci) in general, and on the example of concreate calculations, is performed in particular.
\end{abstract}

\section{Keywords}

Insurance, agricultural insurance, classical insurance scheme, parametric insurance scheme, insurance products, index, weather risk, weather conditions.

Prokopchuk, O., Prokopchuk, I., Mentel, G. and Bilan, Y. (2020) "Parametric Insurance as Innovative Development Factor of the Agricultural Sector of Economy", AGRIS on-line Papers in Economics and Informatics, Vol. 12, No. 3, pp. 69-86. ISSN 1804-1930. DOI 10.7160/aol.2020.120307.

\section{Introduction}

One of the key features of agriculture is its dependence on natural conditions. Along with price volatility, the presence of commercial risk and raiding, Ukrainian farmers are also suffering from weather freaks. Insurance is called to minimize losses from the latter. That is a system of economic relations to guarantee insurance protection in order to ensure the income stability and the available property conservation (Pointer and Khoi, 2019).

As a result, insurance of agricultural products (Ukrainian agricultural insurance system) is one of the key components of such a system that provides risk management in the agricultural sector and contributes to creating the basis for sustainable economic growth in agricultural production.
At the same time, the agricultural insurance market in Ukraine is still undeveloped, and insurance products are not well-received among farmers, despite the tendency to expand the spectrum and quality of the latter in the context of classical and parametric insurance schemes.

Consequently, a certain imbalance arose - a powerful development of the agri-industrial complex in Ukraine in recent years has not been accompanied by the proper development of the insurance market, which goes against the generally established international practice. After all, the majority of countries in the world where agriculture is successfully developing (the USA, Canada, Spain, China, etc.), are characterized by a high level of agricultural insurance development. 
The fact that Ukraine belongs to the risky farming zone largely determines the dependence of agricultural producers' performance on the influence of weather patterns. Insurance based on weather indices is a real leverage over weather risks, that is, patterns that really reduce the crop yield.

Weather index insurance principles were initiated by Halcrow (1948) and further developed by Dandekar (1977), Skees et al. (1999) theoretically proposed these principles for developing countries and later on empirically tested in Moroco (Skees et al., 2001). Mahul (2001) provided a more formal framework for weather index insurance in agriculture. Using historical precipitation and temperature data, Turvey (2001) illustrated how weather index insurance could be used to address specific-event risks measured at the local level and how preIcpitation and heat insurance could be priced in practice. Weather index insurance provides protection for vulnerable households against specific weather shocks (e.g., precipitation shortage or flooding) by using historical precipitation, yield and related agricultural and weather data (Osgood et al., 2007; Barnett et al., 2008; Gebeltova et al., 2020). A contract is signed between an insurer and a policy holder in advance. Payment is based on the observable intensity of a weather index closely correlated to the yield rather than to the non-observable specific impact on it (Mahul, 2001). The policy holder will get a payout when, for instance, precipitation is below an agreed amount (trigger point) based on automated weather station records. Weather insurance thereby needs evidence of the statistical relationship between the specific weather event being measured and volumetric risk (e.g., crop loss) at the farm level.

Different aspects of the functioning of such an important tool as agricultural insurance were studied by the number of national scientists and practitioners, among them are MartseniukRozaronova (2010); Navrotskyi (2012), Nesterchuk (2018), Polchanov (2013) and others. In their research, the scientists studied the main development trends of the Ukrainian agraricultural insurance market in general and some problematic aspects of its development, generalized historical aspects of its formation and establishing, studied the specific features of insurance legislation, and found out the specific character of the insurance market. Ukrainian scientists researched insurance products and insurance schemes that provide insurance protection of farmers (Nesterchuk et al., 2018).
Some theoretical and practical aspects of agricultural insurance were profoundly investigated by foreign scientists, among them the following should be mentioned: Santeramo (2018); Shiferaw et al. (2015); Barnett and Skees (2008).

It is necessary to mention that foreign scientists provide a profound and elaborated analysis of insurance programs, used in the agricultural insurance. This aspect was covered by foreign researchers in the context of classical, parametric and specific insurance schemes: Fuchs and Wolff (2011), Chantarat et al. (2007); Dalhaus, Musshoff and Finger (2018), Tadesse et al. (2015), Turvey (2001), Odening and Shen (2014).

A great body of scientific literature deals with parametric schemes in the agricultural insurance, that is the index insurance products for agriculture. This aspect is sufficiently and intimately researched by the following foreign scientists Barnett et al. (2007), Weber et al. (2015), Sarris (2013), Micntosh et al. (2013), Kocisova et al., 2018, Morkūnas et al. (2018), Walewicz (2018), Malyovanyi et al. (2018), Grmanová and Strunz (2017).

These are key potential advantages of weather index insurance over traditional crop insurance schemes, but many pilot projects show that significant improvements in product design and implementation strategies are still needed, especially to enhance demand and uptake.

At the same time, there are a number of problems related to the functioning of parametric insurance schemes, in particular at the level of developed and developing countries, which are described in sufficient detail by foreign researchers. First of all, it concerns the problem of reliable and systematic data availability.

Thus, Weber et al. (2015) deal with the common problem of developing countries in which yield data is often only available on an aggregated level, and weather data is only accessible for a low number of weather stations. The insurance products are modeled for different inter-regional and intraregional risk aggregation and risk coverage scenarios.

The findings suggest that index-based weather insurance products bear a large risk mitigation potential on an aggregated level. As a result, meso-level insurance should be recognized by institutions with a regional exposure to cost-related weather risks as part of their riskmanagement strategy. 
Despite continued pilot testing of weather index insurance products in low income countries, its actual uptake has been far below expectations (Micntosh et al., 2013; Walewicz, 2018). The high price (premium) and lack of trust in the index and its ability to properly predict the risk of loss as well as the credibility of the insurance providers are key factors negatively influencing the demand for weather index insurance (Barnett and Skees, 2008). Turvey (2001) shows that the low demand for weather index insurance by poor farmers is a rational response to basis risk. For higher uptake, weather index insurance should be cheaper than the current risk management practices of smallholders, such as reliance on social networks and selfinsurance mechanisms by owning assets (Micntosh et al., 2013). Others argue that promoting access to productive assets (e.g., land), credit, improved seeds, better agricultural practices and rural infrastructure are the key factors for the poor to build their own capital to self-insure in case of disaster. However, it is difficult for the poor to build capital for climate risk management and risk transfers (insurance) in the short run as current consumption competes with future savings. Insurance and credit instruments for smallholders may need to be seen as essential complements rather than substitutes for risk-reducing and profitable technological innovations. This is particularly relevant as technological solutions will be inadequate in managing production risks caused by severe climate shocks and extreme events, expected under progressive climate change.

At the same time, nowadays the Ukrainian market of agricultural insurance is still undeveloped, and insurance products are not in a great demand among farmers. Moreover, parametric insurance products, at the Ukrainian insurance market are innovative and now they are at the introduction stage. Considering this, the use of innovative practices and methods in the agricultural insurance at the current stage requires further heightened attention.

\section{Aims}

The purpose of the paper is to investigate the application of parametric (index) schemes of insurance in the agricultural sector of economy with a focus on weather index insurance products, outlining their advantages and disadvantages and, from this, justification of the feasibility of using the authors' proposed combined weather index $(\mathrm{Ci})$, which consider and combine several parameters at a time and, thus, is able to minimize the impact of the combination of weather risks at the regional level.

\section{Materials and methods}

The theoretical and methodological basis of research is the works of domestic scientists and practitioners, as well as foreign ones involved in researching the market of agricultural insurance services in general and the issues of developing an effective system of agricultural insurance, in particular. The following methods of research as an economic-statistical, abstract-logical, graphic and scientific generalization are used.

To achieve the stated goal, the following general scientific methods of scientific cognition and research of economic phenomena were used, in particular the dialectical cognition method was used to analyze scientific research papers on the national and foreign issues of effective functioning of the insurance market in general and the research of available insurance services for agricultural producers.

The empirical research method was used to evaluate the current state and development of the object of our research.

To compare the key insurance schemes, in particular in the context of classical and parametric insurance products, we applied comparative analysis. Tabular and graphical methods were applied to systematize and visualize numerical material. Abstractlogic approach allows to generalize the findings of the research and to draw the conclusions.

In practice, the economic-statistical method is used in the study of mass phenomena, processes, facts and the identification of trends and patterns of their development. It also makes it possible to determine the quantitative effect of individual factors on the result of the study and identify the main factors that led to changes in the course of economic processes. In this study, this method is one of the main methods. After all, using the method of mathematical statistics, namely, multivariate analysis of variance, the justification of individual parameters influence (the average monthly air temperature, precipitation amount and relative humidity) on the yield of the agricultural crop is carried out (corn in Uman district of Cherkasy region). The main features of this method application in this study are described below.

\section{Calculation and usage patterns of the combined weather index $(\mathrm{Ci})$ from a regional perspective}

In the framework of this research, we will consider the feasibility of using a combined weather index, which put several parameters together, so-called 
triggers, in terms of Uman district of Cherkasy region. The source of the basic data describing agri-meteorological conditions of crops vegetation (in this case, grain maize) is the observation results of weather conditions conducted at Uman meteorological station, located in Uman district of Cherkasy region (period: in 2002-2017 timeframe, that is, an interval of 15 years).

In this case, the combined weather index is used, in particular, the boundary values of the three parameters: the amount of precipitation, relative humidity and the air temperature during the critical periods of crop vegetation (flowering and grain filling - June-July of the month), which determine the critical values of corn yield for grain, are used.

The grain maize yield data for this research were based on a long stationary field experiment (conducted since 1964) by the Department of Agrochemistry and Soil Science of Uman National University of Horticulture, based on a 10 -field crop rotation (spring barley + clover, clover, winter wheat, sugar beet, maize, peas, winter wheat, maize for silage, winter wheat, sugar beet). In the crop rotation organic fertilizers (manure $9 \mathrm{t}, 13.5 \mathrm{t}, 18 \mathrm{t})$, mineral $\left(\mathrm{N}_{45} \mathrm{P}_{45} \mathrm{~K}_{45} ; \mathrm{N}_{90} \mathrm{P}_{90} \mathrm{~K}_{90}\right.$; $\mathrm{N}_{135} \mathrm{P}_{135} \mathrm{~K}_{135}$ ) and organo-mineral (manure $4.5 \mathrm{t}$ $+\mathrm{N}_{22} \mathrm{P}_{34} \mathrm{~K}_{18}$; manure $9 \mathrm{t}+\mathrm{N}_{45} \mathrm{P}_{68} \mathrm{~K}_{36}$; manure $13.5 \mathrm{t}$ $+\mathrm{N}_{67} \mathrm{P}_{102} \mathrm{~K}_{54}$ ) are applied in crop rotation (Table 1). One of the intermediate stages of further research will be the separation from the above set of fertilizer systems optimal and the subsequent research stages based on the indicators of the latter.

The values of weather parameters (precipitation, relative humidity, air temperature) are taken from the data of Uman meteorological station.

For grain maize, the critical period of time is the flowering and grain filling. This period lasts about two months (usually in June and July). At the same time, it should be emphasized that this period of time is determined in each region individually. It is during this period that sufficient moisture is required (both in the form of precipitation and relative air humidity) so that the grain gets moisture and it is very important that there are no extremely high temperatures at this time interval (especially during flowering).

The key stages of further research are as follows:

1. To determine the effect of weather conditions (heat, air humidification, drought) and elements of agritechnology (fertilizer systems) on the formation grain maize yield.

2. To find an optimal fertilizer system as a key element of agritechnology for this crop and conduct the futher stages of research based on the latter.

3. To characterize and determine the effect of three identified weather risks, measured by certain parameters (heat, cold - temperature; air humidification - relative humidity; drought - precipitation) on the grain maize yield at a certain critical stage of crop vegetation (flowering and grain filling).

4. To calculate the combined weather index $\left(C_{i}\right)$ and, accordingly, all other key parameters that characterize it (the index step, in particular; the interval step, determining the insured event occurence; the justification of the scale of insurance payments as a result of insured event occurence, etc.).

Determination of the weather conditions effect (heat - temperature; air humidification - relative humidity; drought - precipitation) and agritechnology elements (fertilizer systems) on the formation of grain maize yield

\begin{tabular}{|c|c|c|c|c|c|c|c|}
\hline Fertilizer & & Mean & Median & Min & Max & Std.Dev. & Coef.Var. \\
\hline No fertilizers & No fertilizers & 47.9 & 45.65 & 20.0 & 83.6 & 13.48 & 28.09 \\
\hline $\mathbf{N}_{45} \mathbf{P}_{45} \mathbf{K}_{45}$ & $1 \mathrm{NPK}$ & 58.6 & 57.6 & 28.5 & 89.0 & 13.76 & 23.48 \\
\hline $\mathbf{N}_{90} \mathbf{P}_{90} K_{90}$ & 2 NPK & 67.0 & 66.7 & 35.7 & 89.6 & 13.19 & 19.69 \\
\hline $\mathbf{N}_{135} \mathbf{P}_{135} \mathbf{K}_{135}$ & 3 NPK & 72.8 & 72.1 & 42.4 & 95.8 & 13.44 & 18.45 \\
\hline Humus $9 \mathrm{t}$ & $2 \mathrm{Hn}$ & 59.1 & 61.2 & 27.7 & 87.0 & 14.48 & 24.51 \\
\hline Humus $13.5 \mathrm{t}$ & $3 \mathbf{H n}$ & 64.6 & 65.5 & 32.4 & 92.0 & 14.79 & 22.88 \\
\hline Humus $18 \mathrm{t}$ & $4 \mathrm{Hn}$ & 67.9 & 66.45 & 38.1 & 93.0 & 13.95 & 20.52 \\
\hline Humus $4.5 \mathrm{t}+\mathrm{N}_{22} \mathrm{P}_{34} \mathrm{~K}_{18}$ & $1 \mathrm{Hn}+\mathrm{NPK}$ & 60.5 & 60.2 & 30.2 & 92.0 & 14.01 & 23.15 \\
\hline Humus $9 \mathrm{t}+\mathrm{N}_{45} \mathbf{P}_{68} \mathbf{K}_{36}$ & $2 \mathrm{Hn}+\mathrm{NPK}$ & 70.5 & 70.3 & 38.1 & 93.8 & 13.39 & 18.97 \\
\hline Humus 13.5 $t+N_{67} P_{102} K_{54}$ & $3 \mathrm{Hn}+\mathrm{NPK}$ & 77.0 & 76.7 & 47.2 & 99.7 & 12.81 & 16.64 \\
\hline
\end{tabular}

Source: Data samples for statistical processing are formed from the results of researches obtained during 2002-2017 (that is, the interval of 15 years) 
The variation coefficients of the data samples of different study years ranged from 16 to $24 \%$, corresponding to a small and moderate variation (Table 1). This indicates that weather conditions had an effect on the formation of grain maize yield. The most stable samples were data obtained for maximum fertilization, while the control study (variant without fertilizer) had the most variation (Coef. Var. $=28.09$ ). The introduction of fertilizers

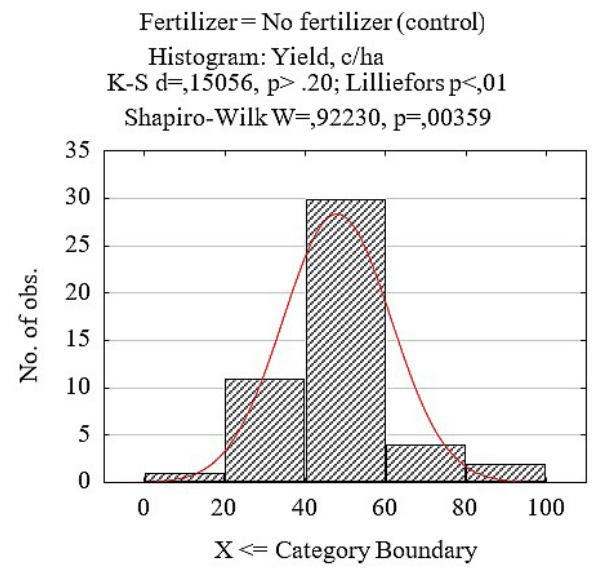

Fertilizer $=2 \mathrm{NPK}$ Histogram: Yield, c/ha

$\mathrm{K}-\mathrm{S} \mathrm{d}=, 07164, \mathrm{p}>.20$; Lilliefors $\mathrm{p}>.20$ Shapiro-WilkW=,96767, $\mathrm{p}=, 20516$

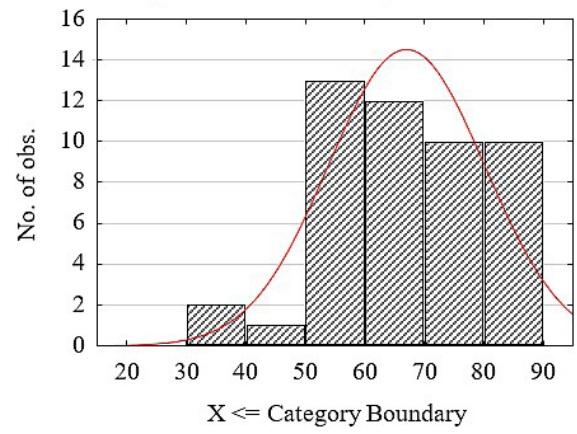

Fertilizer $=2 \mathrm{HN}$

Histogram: Yield, c/ha

$\mathrm{K}-\mathrm{S} \mathrm{d}=, 09578, \mathrm{p}>.20$; Lilliefors $\mathrm{p}>.20$

Shapiro-WilkW=,96861, p=,22357

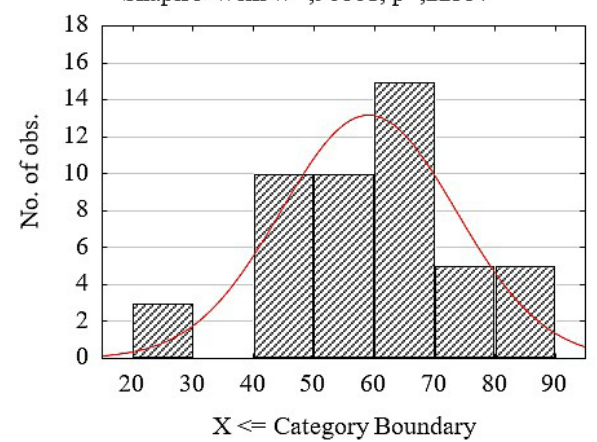

contributed to the yield increase.

Analyzing the data samples, the theory of correct distribution was confirmed in almost all cases (Figure 1). An exception to the above is a sample of data obtained without fertilization, as evidenced by a low probability score for the Shapir-Wilka criterion $(p=0.0035)$. Therefore, a further research was conducted using parametric statistics methods.

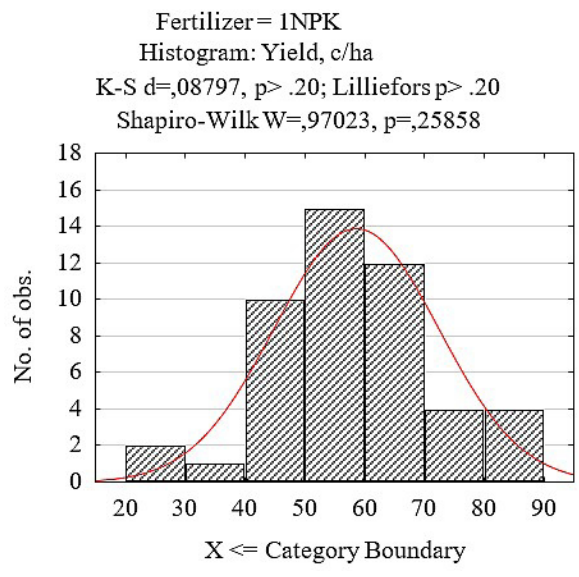

Fertilizer $=3 \mathrm{NPK}$

Histogram: Yield, c/ha

$\mathrm{K}-\mathrm{S} \mathrm{d}=, 09760, \mathrm{p}>.20$; Lilliefors $\mathrm{p}>.20$

Shapiro-WilkW=,96989, $\mathrm{p}=, 25084$

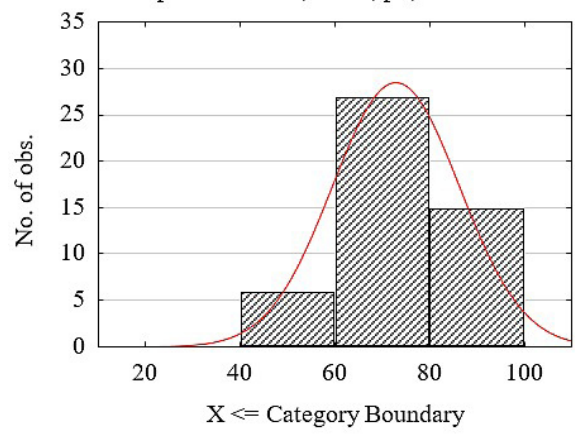

Fertilizer $=3 \mathrm{Hn}$

Histogram: Yield, c/ha

$\mathrm{K}-\mathrm{S} \mathrm{d}=, 09048, \mathrm{p}>.20$; Lilliefors $\mathrm{p}>.20$

Shapiro-WilkW=,97386, $\mathrm{p}=, 35529$

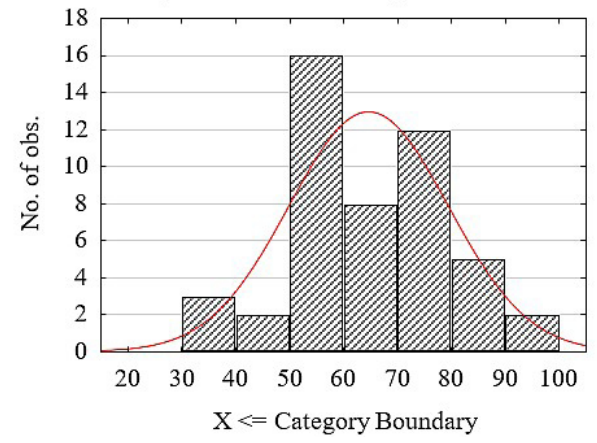

Source:Authors' own calculations based on the conducted research

Figure 1: Data distribution histograms (to be continued). 

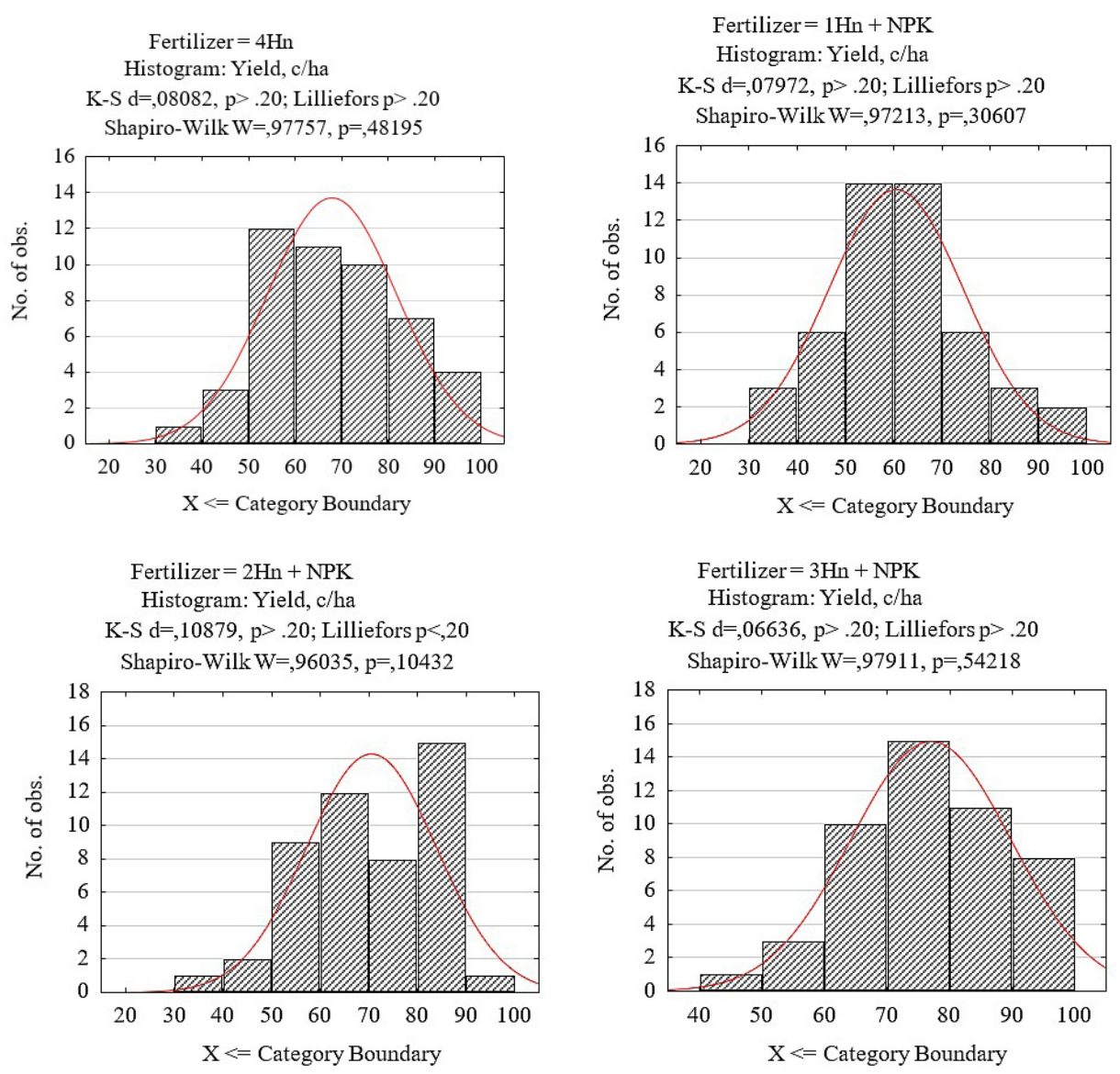

Source: Authors' own calculations based on the conducted research

Figure 1: Data distribution histograms (continuation).

After conducting multivariate dispersion analysis (Factorial ANOVA), the reliable effect of the environment and fertilizer system on the formation of grain maize yield was confirmed (Table 2). The weather conditions that were different in the study years (Partial eta-squared $=0.96$ ) had the biggest effect on the crop yield formation. To a lesser extent, however, the elements of agritechnology also significantly influenced (Partial eta-squared $=0.91)$. In addition, there was a reliable link between the factors (Partial eta-squared $=0.58$ ). As a result, it is arguable that the negative effect of environment can be partially minimized by agritechnology of cultivation.

Selection of optimized fertilizer system as a key element of crop agritechnology

The highest yield of the analyzed crop was recorded in 2011 and in 2014 and was 88.4 and 84.8 centners per hectare, respectively (Figure 2). The worst crop yield was in 2007 (35.9 c/ha). In other years, the crop yield varied from 50 to $75 \mathrm{c} / \mathrm{ha}$.

It should be noted that the fertilizer application contributed to the yield increase. The biggest effect was after the application of 3 NPK (yield - 72.8 centners/ha), $4 \mathrm{HN}$ (yield - 68.0 cent/ ha), and $3 \mathrm{HN}+$ NPK (yield -77.0 centner/ha). As a consequence, these treatments can be recommended to farms for the efficient cultivation of grain maize. At the same time, for a further research, samples obtained after the application of 3 NPK fertilizers were used, since this method is most commonly used in farms. Therefore, all further calculations were carried out according to 3 NPK $\left(\mathrm{N}_{135} \mathrm{P}_{135} \mathrm{~K}_{135}\right)$ fertilizer systems.

\section{Characterization and determination of the effect level of the specified weather risks (heat - temperature; air humidification - relative humidity; drought - precipitation) on the grain maize yield in the period of flowering and grain filling}

Analyzing weather conditions (daily mean temperature, relative humidity and total precipitation), it can be stated that they significantly change over the study years (Figure 3 ). 


\begin{tabular}{|l|r|r|r|r|c|c|}
\hline Effect & \multicolumn{1}{|c|}{ SS } & \multicolumn{1}{c|}{ MS } & \multicolumn{1}{c|}{ F } & p & Partial eta-squared & Non-centrality \\
\hline Intercept & 2004809.68 & 2004809.68 & 229036.03 & 0.00 & 0.99 & 229036.03 \\
\hline Year & 82005.24 & 5467.01 & 624.56 & 0.00 & 0.96 & 9368.54 \\
\hline Fertilizer & 30371.14 & 3374.57 & 385.52 & 0.00 & 0.91 & 3469.69 \\
\hline Year*Fertilizer & 4006.68 & 29.67 & 3.39 & 0.00 & 0.58 & 457.73 \\
\hline Error & 2801.04 & 8.75 & & & & \\
\hline
\end{tabular}

Source: Authors' own calculations based on the conducted research

Table 2: Univeriate tests of significance and factor effects for grain maize yield.
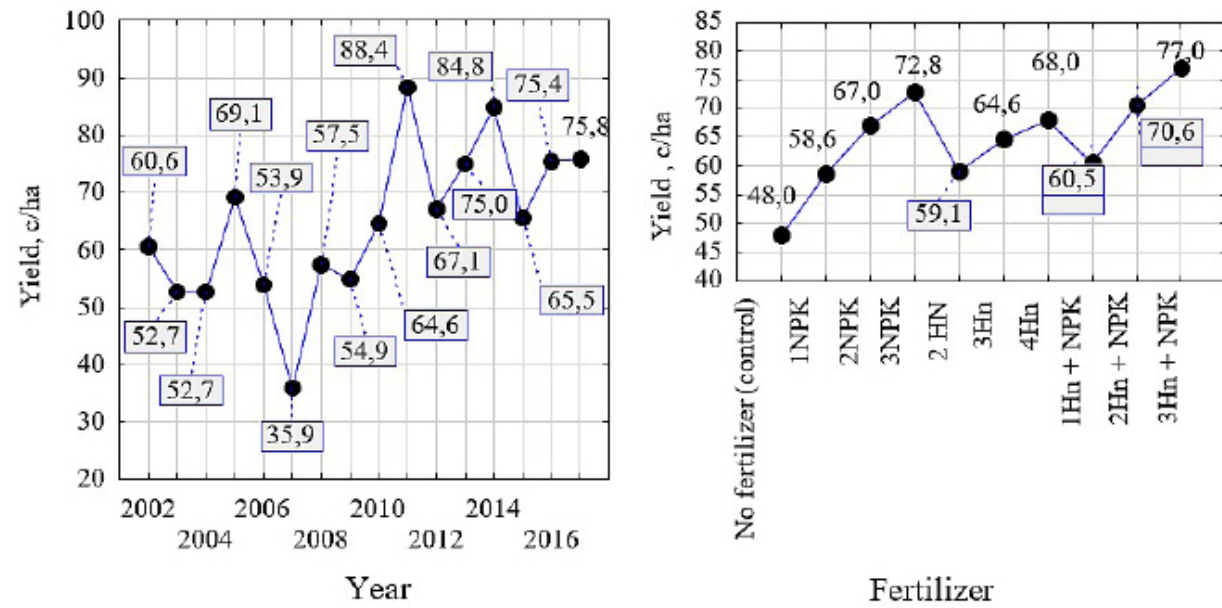

Fertilizer

Source: Authors' own calculations based on the conducted research

Figure 2: Effective hypothesis of grain maize yield distribution depending on level and fertilizer system and the year of sudy
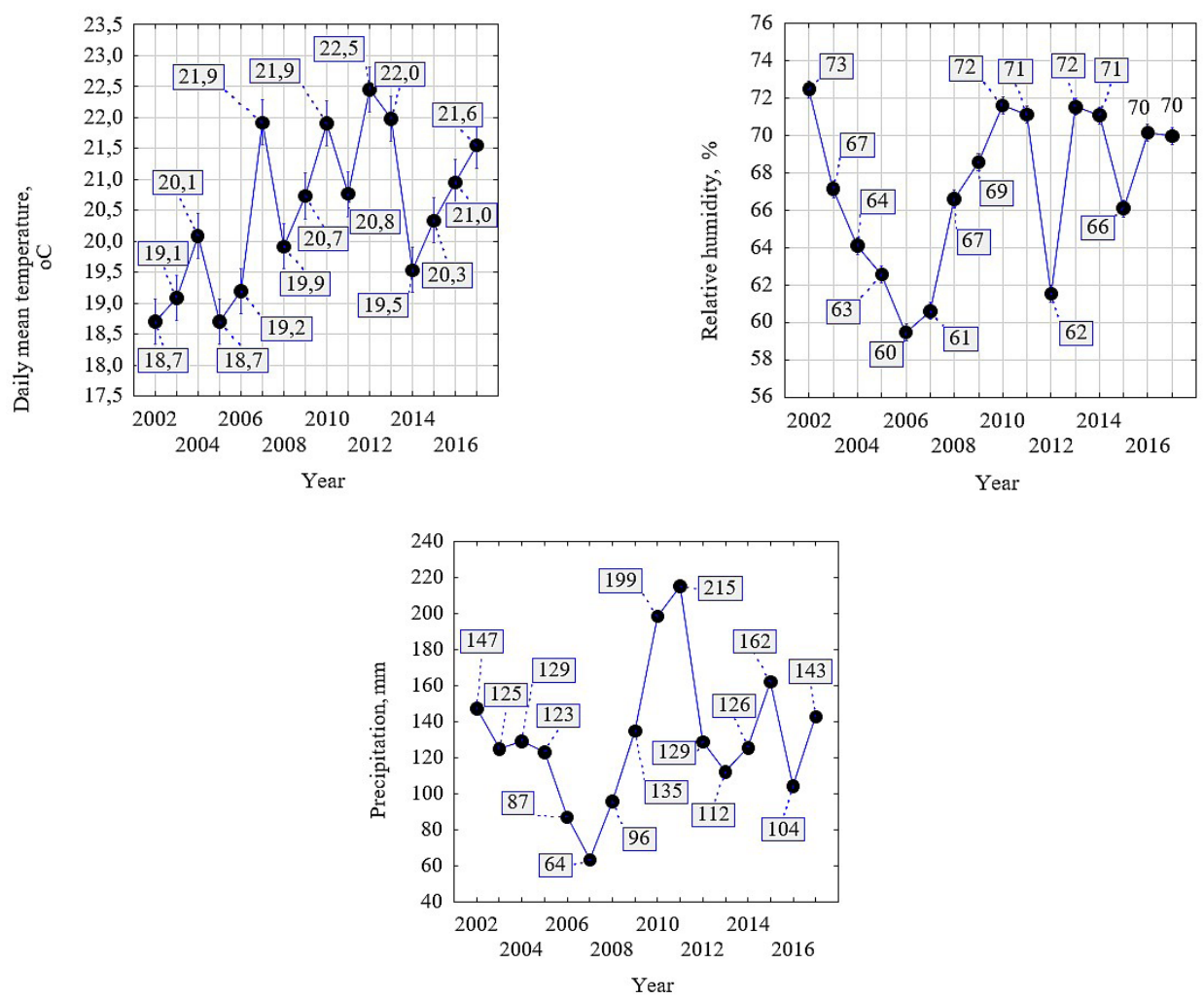

Source: Authors' own calculations based on the conducted research

Figure 3: Effective hypothesis of environmental parameters distribution depending on the year of research. 
The strongest proved correlation dependence was recorded between yield, total precipitation $(\mathrm{r}=0.43)$ and relative humidity $(\mathrm{r}=0.60)$ (Figure 4). No correlation between daily mean temperature and crop yield was recorded.

The positive effect of total precipitation increasing is confirmed by the dispersion analysis (Figure 5). After mathematical generalization of the corresponding dependence in the form of the desirability function, it was established that the least amount of precipitation $(60-70 \mathrm{~mm})$ was critical for the crop yield.
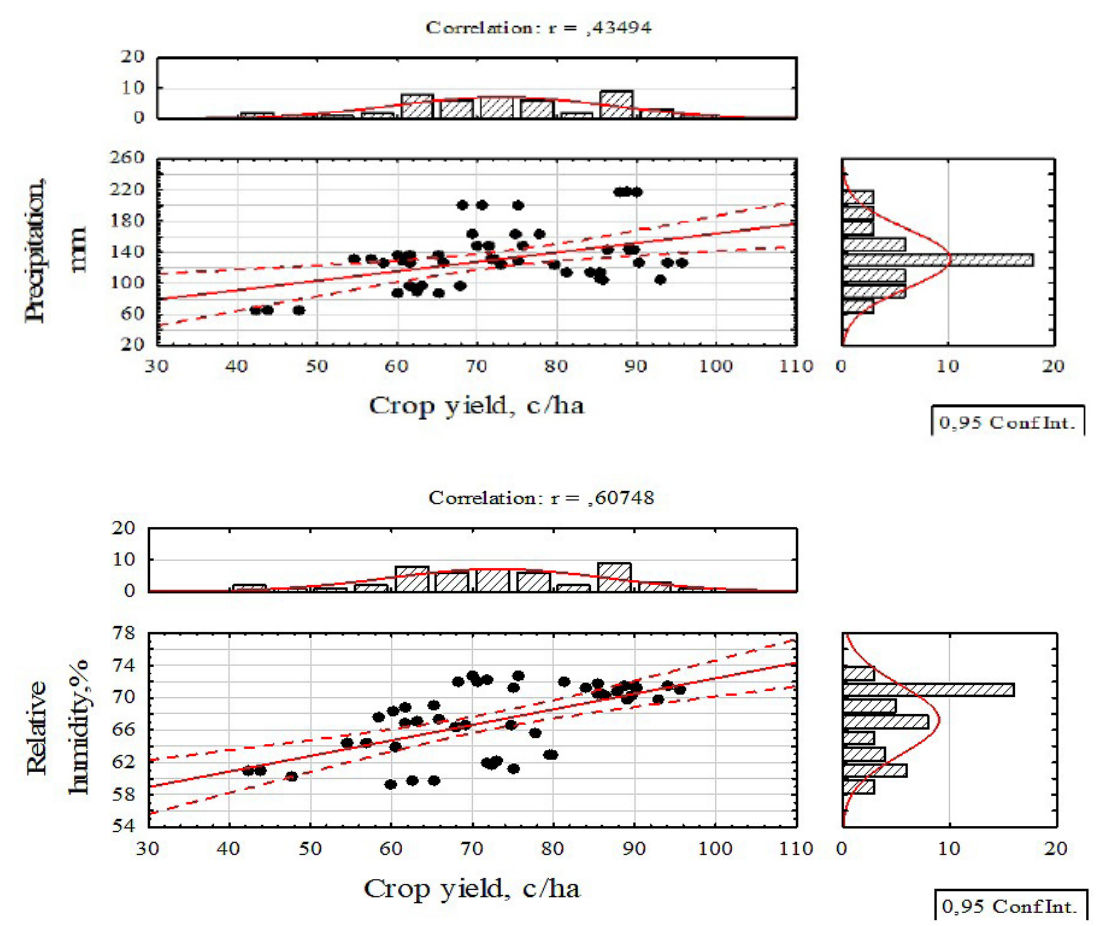

Source: Authors' own calculations based on the conducted research

Figure 4: Correlation between environment factors and crop yield.
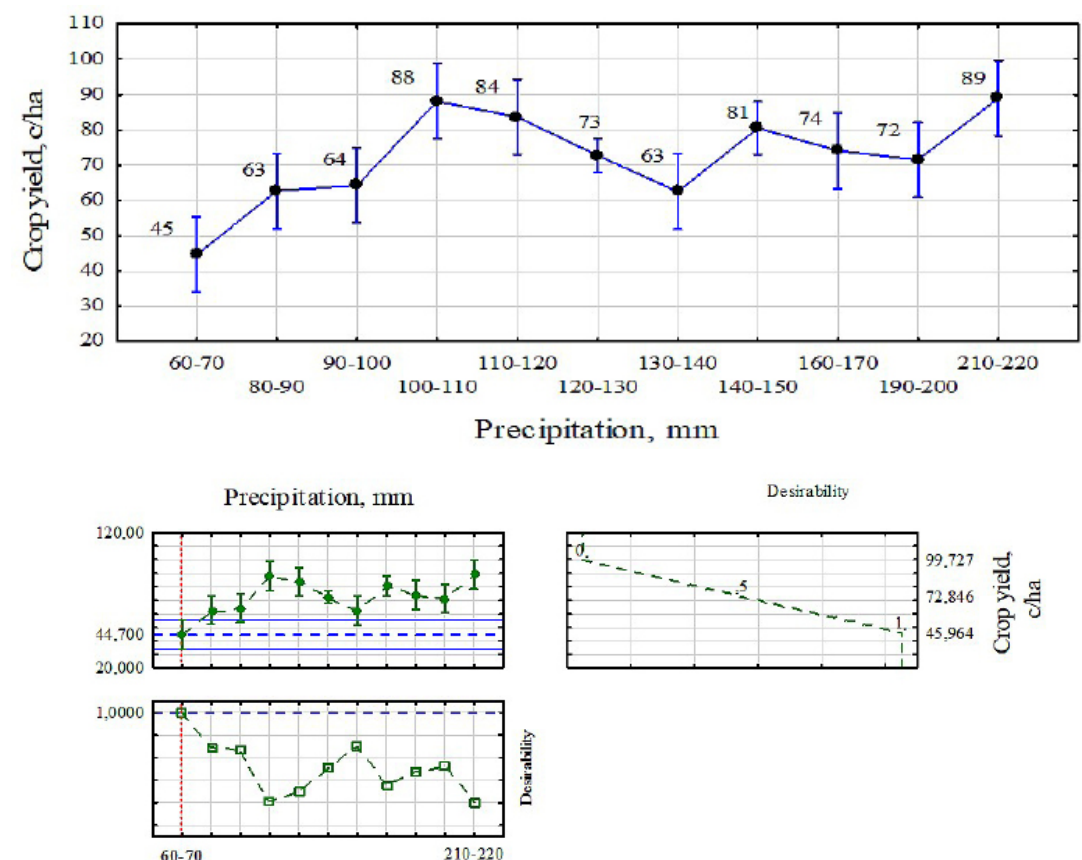

Desirability

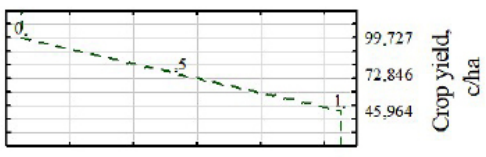

Source: Authors' own calculations based on the conducted research

Figure 5: Effect of total precipitation on grain maize crop yield. 
The probability of temperature effect on grain maize crop yield was $70 \%$ (Figure 6). It was recorded that the optimum temperature for cultivation was 21-22 ${ }^{\circ} \mathrm{C}$, relatively lower and higher temperatures in general had a negative effect on crop yield. Analyzing the desirability function, it is arguable that for the grain maize higher temperatures were critical $\left(22-23^{\circ} \mathrm{C}\right)$.

The highest and the most stable crop yield was recorded at the highest relative humidity of 70-75\% (Figure 7). Critical for it was the lowest relative humidity $-55-60 \%$.
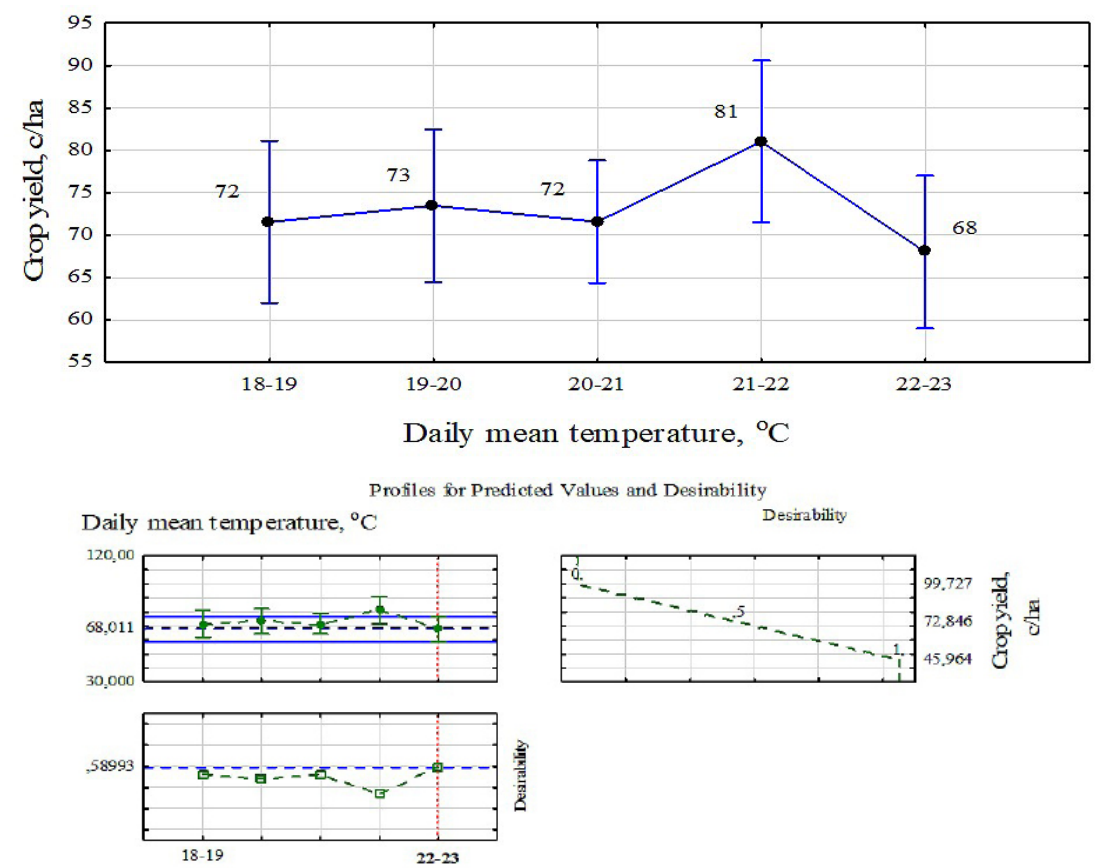

Source: Authors' own calculations based on the conducted research

Figure 6: Temperature effect on grain maize crop yield.
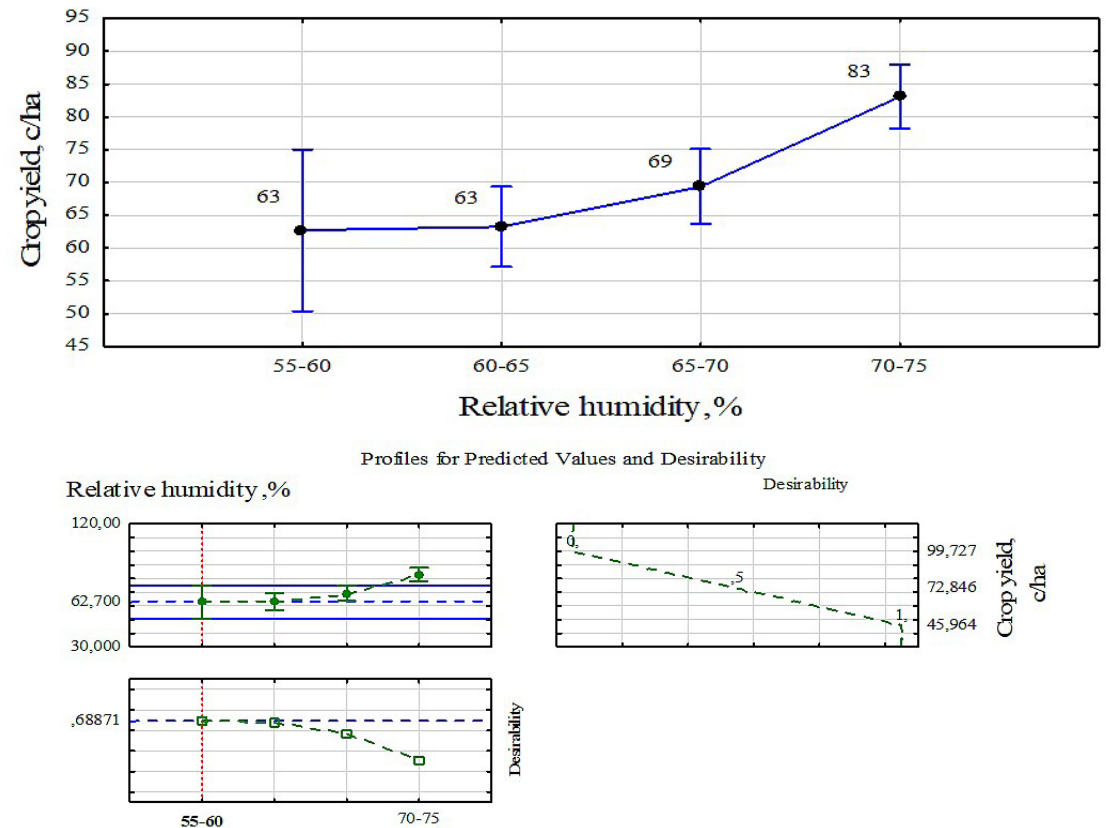

Source: Authors' own calculations based on the conducted research

Figure 7: Relative humidity effect on grain maize crop yield. 


\section{Results and discussion}

Classification characteristics of insurance products in agricultural business of Ukraine

At this stage, Ukrainian agricultural insurance market is presented in the context of the classic and parametric schemes of insurance (Figure 8). According to the classic scheme, agricultural risks were insured in the context of multi-risk and mono risk product offers with their multiterminal marketing line. Among the classic insurance products on Ukrainian agricultural insurance market, multi-risk product offers (both in the winter and in spring-summer period) have got the most widespread, providing a full and packaged insurance protection of crops in general and field crops, in particular. Under the parametric (index) scheme, agricultural risks were insured in the context of weather and yied index insurance products, dominant among which are weather index insurance products.

Analyzing the data of Figure 8, it should be noted that the share of the insured area in the total crop area under the results of 2017 and under the classical insurance scheme was $2.5 \%$, while for the parametric $-1.6 \%$.

The total number of insured crops in Ukraine in 2017 amounted to 1077 thousand hectares, of which 420 thousand hectares were insured using the index scheme of insurance (that is, this insurance scheme covered almost $40 \%$ of the total area of insured crops in Ukraine). The number of concluded insurance contracts dominated according to the classic insurance scheme as well. At the same time, given the innovative nature of this insurance scheme in Ukrainian insurance practice, its achievements in the domestic agricultural insurance market are quite significant (its implementation in the framework of pilot projects took place from 2016).

Considering the question of parametric insurance in the context of its classification characteristics, it should be noted that there are many varieties of index insurance products, while Ukrainian insurance practice at this stage is limited to the main two of them: weather and yield. Weather index insurance products are dominated among the recent. In addition, it should be noted that their implementation is still limited in terms of territorial coverage (these products cover only a few regions of the country and are currently distributed to a limited range of crops (wheat and maize). Thus, at present, parametric insurance at the Ukrainian agricultural insurance market functions within the framework of a pilot project, which gives a significant opportunity for its further development, due to its numerous advantages.

Advantages and disadvantages of index insurance products for the agricultural sector of economy

Insurance on the basis of weather indices is the most suitable for agricultural production in the Ukrainian regions, where crop loss due to drought, excessive overmoisturising and freezing are widespread. The combination of advantages and disadvantages of index insurance products for the agricultural sector of economy is grouped in Figure. 9.

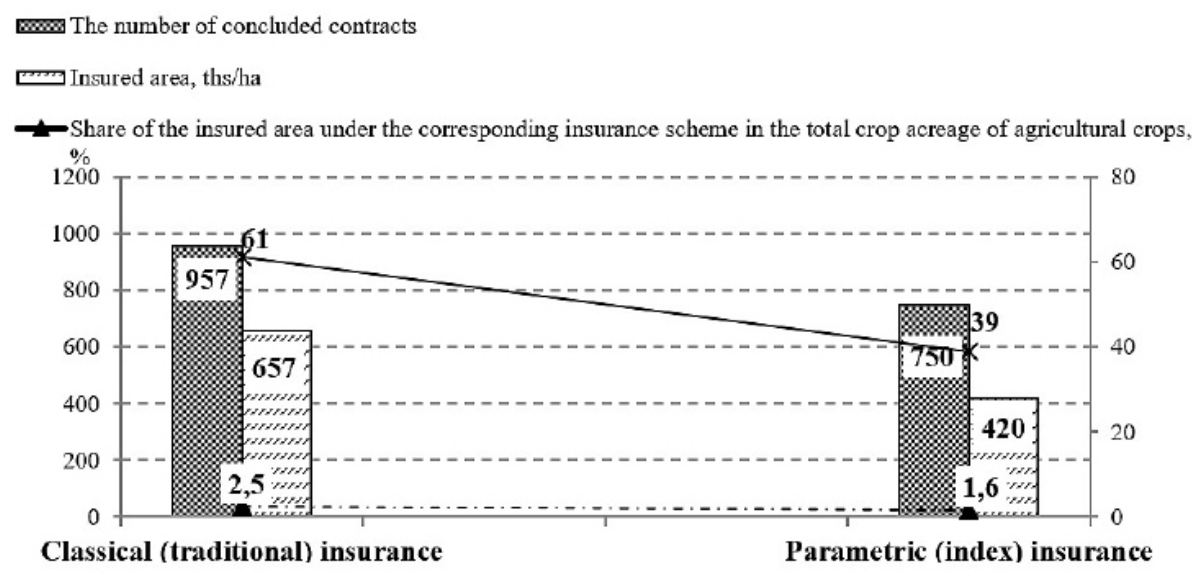

Source: Data of the National Commission on State Regulation in the FinanIcal Services Markets (calculated and proposed by the authors)

Figure 8: Ukrainian agricultural insurance market in the context of classical and parametric insurance schemes (2017). 


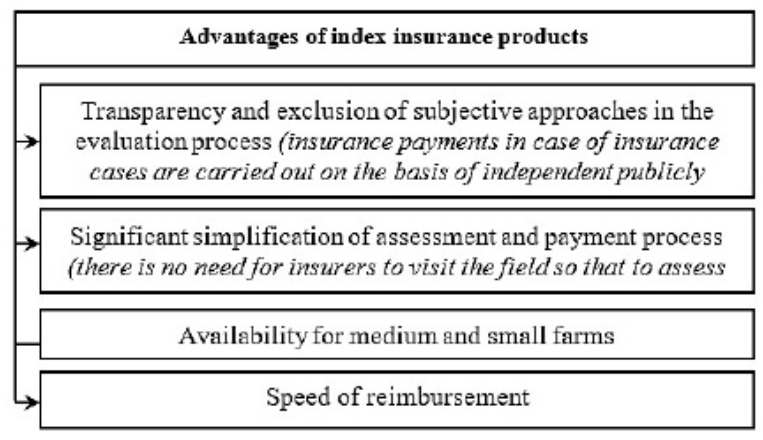

\begin{tabular}{|c|}
\hline Disadvantages of index insurance products \\
\hline $\begin{array}{c}\text { Absence of an individual approach to each insurance object } \\
\text { (the individual approach to each farm is lost (field, object, }\end{array}$ \\
$\begin{array}{c}\text { 'Basis' risk } \\
\text { (risk probability, but no compensation due to failure to reach } \\
\text { the index of the set limit) }\end{array}$ \\
Poor infrastructure \\
(lack of meteorological stations and equipment, distortion of \\
data, lack of long-term array of reliable data)
\end{tabular}

Source: Author's generalization

Figure 9: Advantages and disadvantages of index insurance products for the agricultural sector of economy.

Analyzing the Figure 9, it should be noted that index insurance products for the agricultural sector of economy have a number of advantages and disadvantages.

In index insurance there are all the essential elements of traditional insurance - there is a subject of insurance, certain risks, as well as the price and the mechanism of payment calculation. In traditional (classic) insurance, the amount of damages as well as the amount of compensation are determined by agents who can make such an evaluation differently and, accordingly, the amount of the loss will also differ. As a result, objectivity of evaluation is lost and process is delayed (especially when it comes to mass losses). While index insurance has a clear algorithm for determine the damage, which is based only on certain indicators, such as weather data and mathematical models.

As a result, it should be noted that index insurance helps to overcome some disadvantages of classical insurance.

\section{Weather index insurance products}

At the heart of weather index insurance is the onset of certain weather events, in case of which the possibility of obtaining an insurance payment appears. At the same time, the key task of the developers of such weather indices is the maximum approximation of two facts: the reduction of crop yield and those weather phenomena that are the basis of this index and are determined and described by certain parameters (triggers) (Figure 10).

That is, index insurance works depending on some parameter (trigger) or their combination (the index can take into account and lay down several parameters at a time). Thus, insurance based on weather indices is a real lever of weather effects, that is, factors that actually reduce the crops yield.

\section{Functioning mechanism aspects of the combined weather index}

It should be also said that the index can take into account and lay out several parameters together, so-called triggers. Let us say not only the amount

\begin{tabular}{|c|c|c|c|}
\hline \multicolumn{4}{|c|}{ WEATHER INDEX INSURANCE } \\
\hline \multicolumn{4}{|c|}{ is carried out by weather risks, measured by certain parameters } \\
\hline \multicolumn{4}{|c|}{ Weather risks } \\
\hline 35 & 35 & Sh & 25 \\
\hline $\begin{array}{c}\text { Heat, cold } \\
\text { (extreme high and } \\
\text { low temperatures) }\end{array}$ & $\begin{array}{c}\text { Drought, } \\
\text { waterlogging } \\
\text { (full absence of } \\
\text { precipitation, insufficient } \\
\text { or excessive amount) }\end{array}$ & $\begin{array}{c}\text { Air } \\
\text { humidification } \\
\text { (air saturation } \\
\text { with water) }\end{array}$ & Hurricane \\
\hline $\begin{array}{c}\text { parameter } \\
\text { (trigger) }\end{array}$ & $\begin{array}{l}\text { parameter } \\
\text { (trigger) }\end{array}$ & $\begin{array}{l}\text { parameter } \\
\text { (trigger) }\end{array}$ & $\begin{array}{c}\text { parameter } \\
\text { (trigger) }\end{array}$ \\
\hline Temperature, ${ }^{\circ} \mathrm{C}$ & Precipitation, $\mathrm{mm}$ & $\begin{array}{c}\text { Relative } \\
\text { humidity, \% }\end{array}$ & $\begin{array}{c}\text { Wind force, } \\
\mathrm{m} / \mathrm{s}\end{array}$ \\
\hline
\end{tabular}

Source: Author's development

Figure 10: Insurance coverage peculiarities of agricultural producers on the basis of weather indices. 
of precipitation, but also the air temperature, humidity and at the same time take into account the effect of these parameters in different phases of crio vegetation in different ways. For example, a lack of moisture during the grain filling period and extreme high temperatures at flowering time will be more damaging to the future harvest than in other periods, so the index may provide for the deviations payment of the parameters in this period at the maximum size.

Index insurance, as already noted above, refers to the parametric type of insurance. Index - a special indicator that characterizes the effect of a certain risk (set of risks) intensity on the crop yield in the definite development phases. In this research, the combined weather index $(\mathrm{Ci})$ is a special indicator that characterizes the impact intensity of the weather risks combination, measured by certain parameters (heat, cold - temperature; air humidity - relative humidity; drought - precipitation) on the yield of grain maize in the definite development phases (flowering and grain filling) (Fig. 11). Its limit characterizes an insured event and corresponds to a critical loss of yield for the farmer, which is determined even during the development of the insurance product. The index should accurately show how exactly a certain risk affects the crop yield.

Some aspects related to the grain maize cultivation in Ukraine

As this research is based on the indicators of one of the most important agricultural crops - grain maize, it is worth dwelling on some aspects related to its cultivation patterns in Ukraine.

An important component of the whole grain industry in Ukraine is the maize grain production. Maize in Ukraine is grown as a grain, feed and technical crop. It is characterized by the usage versatility and quite high yield. Analyzing the corn production patterns of grain maize in Ukraine, it should be noted that there is a gradual positive dynamics towards an increase in the production of the latter in 2017 compared to 2005 by 3.5 times. The share of the studied crop in the structure of grain and legume production is significant and in the recent years (2014-2017) it reaches the level of about $40 \%$ (in 2013 grain maize dominated grain and legume structure - its share almost reached $50 \%$ ) (Nesterchuk et al. (2018). Its importance and authority in the crop industry has been analyzed quite rapidly. Since 2005, the main production parameters of the latter have increased by much: crop acreages have grown from 1.711 million hectares (2005) to 4.2 million hectares (2017), croppage - from 7.2 million tons (2005 p.) to 25.1 million tons (2017), and in 2013 received a record 30.1 million tons of maize grain. So far, this industry in Ukraine is under the influence of the global trend, according to which the area under corn increases - in 2016 by $2 \%$, in Ukraine - by $1.4 \%$ for the same period ((Nesterchuk et al., (2018).

The share of grain maize, both in the structure of the crop acreage of agricultural crops and in the structure of crop acreage of grain and leguminous crops, significantly increased over the period under research: in 2017 compared with 2005 - by 2.5 times, both indicators respectively.

Thus, the grain maize production for the analyzed period in domestic practice can be divided
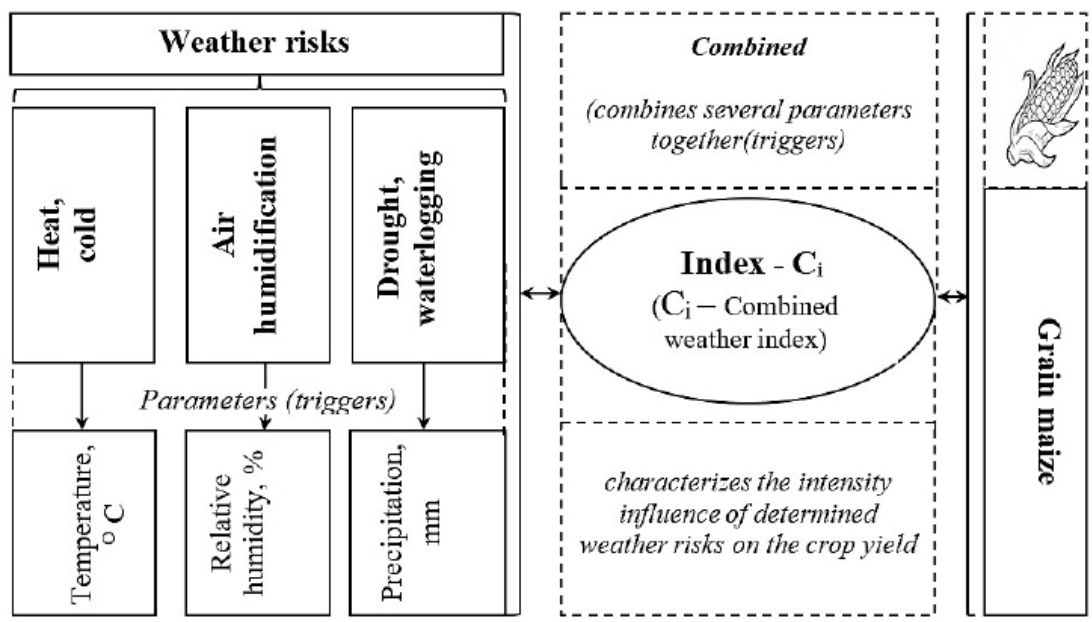

Source: Author's development

Figure 11: Peculiarities of the functioning mechanism of the combined weather index $\left(\mathrm{C}_{\mathrm{i}}\right)$. 
into periods: the first - (2005-2010) and the second - (2011-2017), which are characterized by the tactics of steady slow and rapid growth.

\section{Interpretation and analysis of study results}

Analyzing the obtained data, it should be noted that among the three identified weather risks, the degree of their impact on the grain maize yield was distributed as follows: the greatest effect had such a parameter as precipitation (the maximum value of which resulted in obtaining the top yield); the relative humidity was charactirized by the average degree of effect ( the maximum value of the indicator resulted in the top yield); and the moderate effect made such a parameter as the daily mean temperature (the optimal value of which resulted in top yield) (Figure 12).

Critical values of crop yield of the studied crop were observed for:

- the smallest amount of precipitation $(60-70 \mathrm{~mm})$, which resulted in a reduction in grain maize crop yield by 1.5 times of its average value and almost twice as much as the top size of the latter (Figure 5);

- the lowest relative humidity (55-60\%), which resulted in the reduction in grain maize crop yield by 1.3 times compared with its top value (Figure 7);

- $\quad$ higher air temperatures $\left(22-23{ }^{\circ} \mathrm{C}\right)$ which resulted in $7 \%$ reduction in grain maize crop yield, compared with its average value (Figure 6).
The average value of grain maize crop yield within the framework of this experiment was $73(72.846) \mathrm{c} / \mathrm{ha}$.

Calculation of combined weather index $\left(C_{i}\right)$ and, accordingly, all other key parameters that characterize it

Thus, in conditions of Cherkasy region, namely, Uman district, it is expedient to use a combined weather index reflecting the tandem effect of determined weather risks, which are described by certain parameters, on the reduction of the investigated crop yield.

As an index value, based on the results of this particular study, it is advisable to take optimal values of weather risks, which determine the achievement of an average yield level for a given crop (73 c/ha). Instead, the limit values of weather risks determine the achievement of a critical level of productivity in a given crop and result in the payment of maximum insurance indemnities.

The description of the intervals determining the occurrence of the insured event and the peculiarities of the insurance payments gradation from the author's position, in the context of individual parameters, is presented in Table 3.

The features of the functioning mechanism of the combined weather index $(\mathrm{Ci}$ ) according to the performed calculations are graphically depicted in Figure 13.

As can be seen from Table 3, the size of the insurance indemnity depends on the deviation degree

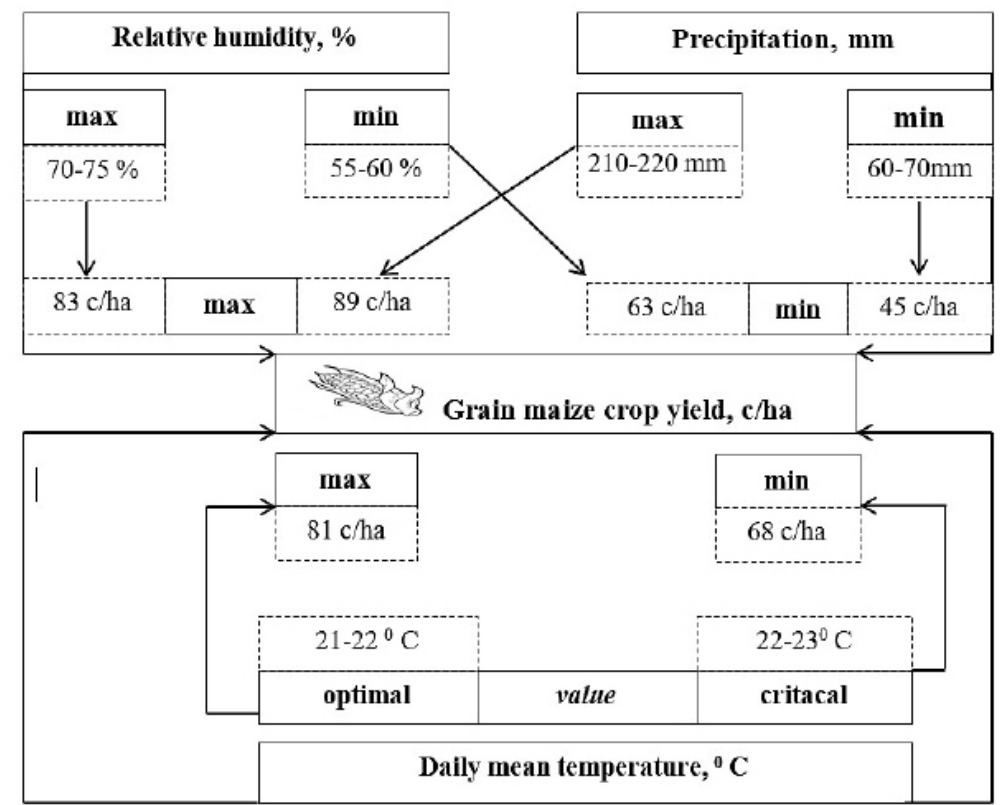

Source: Author's development

Figure 12: Peculiarities of determined weather risks effect on grain maize crop yield. 


\begin{tabular}{|c|c|c|c|c|c|c|}
\hline Weather risks & $\begin{array}{l}\text { Parameter } \\
\text { (trigger) }\end{array}$ & Index value & $\begin{array}{l}\text { Index } \\
\text { step }\end{array}$ & $\begin{array}{c}\text { Insured } \\
\text { event }\end{array}$ & $\begin{array}{c}\text { Gradation } \\
\text { of intervals }\end{array}$ & $\begin{array}{l}\text { The amount } \\
\text { of the insurance indemnity } \\
\text { (\% of the insurance sum) }\end{array}$ \\
\hline \multirow{6}{*}{ Drought } & \multirow{6}{*}{$\begin{array}{l}\text { Precipitation, } \\
\mathrm{mm}\end{array}$} & \multirow{6}{*}{$120-130$} & \multirow{6}{*}{10} & \multirow{6}{*}{$<120-130$} & $110-120$ & 10 \\
\hline & & & & & $100-110$ & 20 \\
\hline & & & & & $90-100$ & 30 \\
\hline & & & & & $80-90$ & 40 \\
\hline & & & & & $60-70$ & 50 \\
\hline & & & & & $<60-70$ & 100 \\
\hline \multirow{3}{*}{$\begin{array}{l}\text { Air } \\
\text { humidification }\end{array}$} & \multirow{3}{*}{$\begin{array}{c}\text { Relative } \\
\text { humidity, \% }\end{array}$} & \multirow{3}{*}{$65-72$} & \multirow{3}{*}{5} & \multirow{3}{*}{$<65-72$} & $60-65$ & 10 \\
\hline & & & & & \multirow{2}{*}{$\begin{array}{r}55-60 \\
<55-60 \\
\end{array}$} & 20 \\
\hline & & & & & & 100 \\
\hline \multirow{3}{*}{ Heat } & \multirow{3}{*}{$\begin{array}{c}\text { Temperature, } \\
{ }^{0} \mathrm{C}\end{array}$} & \multirow{3}{*}{$19-21$} & \multirow{3}{*}{1} & \multirow{3}{*}{$>19-21$} & $21-22$ & 10 \\
\hline & & & & & $22-23$ & 20 \\
\hline & & & & & $>22-23$ & 100 \\
\hline
\end{tabular}

Source: Author's development

Table 3: Key data according to research results.

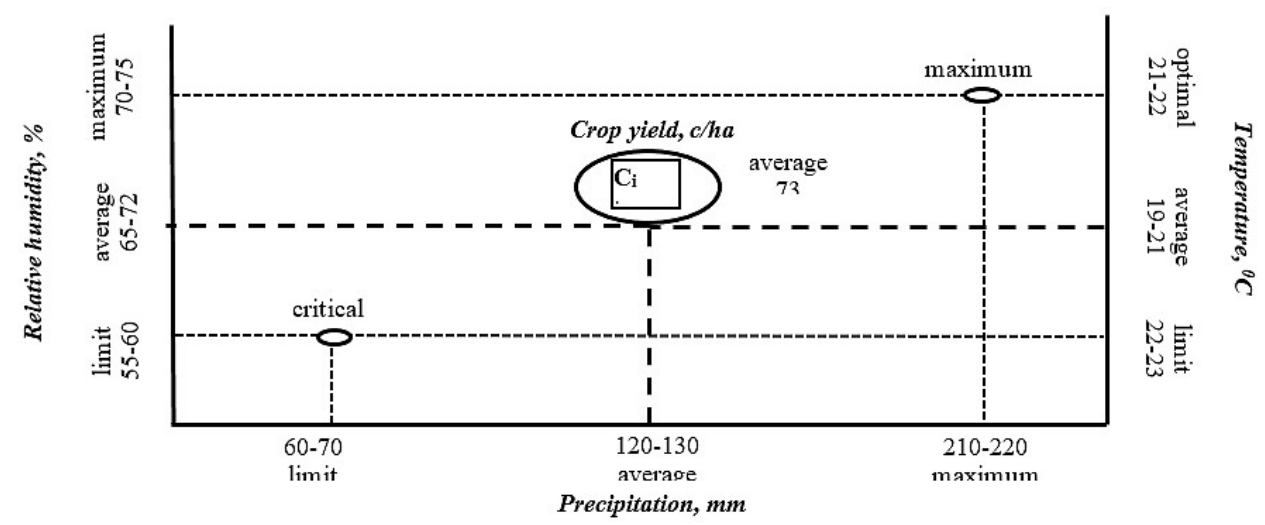

Source: Author's development

Figure 13: Features of the functioning mechanism of combined weather index (Ci) according to the performed calculations.

of the index from the average calculated value (that is, the value of the index 'step').

Based on the obtained results, it is arguable that in the period of 2002-2017, within the framework of this research, an insured event with the terms of payment of maximum insurance indemnity was made in 2002 and during 2015-2017 which was due to the achievement of the limit values of weather risks in the most important periods of plant vegetation - grain maize.

At the same time, it should be noted that insurance companies may view this problem in different ways. So, for the size of the index may be taken not average but the limit values of weather risks described by the appropriate triggers which resulted in the achievement of critical yield level of this crop. In such circumstances, the farmer claims to receive the insurance indemnity in whole.
Other options may also be considered. However, these issues are purely technical and should be agreed at the stage of development of the insurance product and the conclusion of an insurance contract.

It is worth emphasizing that weather indices can be calculated for different crops and vegetation periods, as well as to lay one or more parameters at a time in their basis. At the same time, it should be noted that combined weather indices are more effective.

According to the results of research, it was found that the combined weather indices have specific features that are realized by the possibility of several parameters simultanious arranging. As a result, this, on the one hand, results in a greater complexity in their calculation, while at the same time it allows the effect of weather risks combination to be mitigated. 


\section{Conclusions}

The conducted research allowed to make the following conclusions and generalizations:

1. Ukrainian agricultural insurance market at the modern stage operates in the context of two key insurance schemes: classical and parametric, and also uses a sufficient set of insurance products within each of them, which according to their qualitative characteristics meet the international standards.

A parallel between the key schemes of agricultural risk insurance, including classical and parametric, made it possible to outline the features of each of them:

- the classic insurance scheme is quite widespread both in the context of world and national practices in agricultural risk insurance, while the parametric one is innovative in the Ukrainian market of agricultural insurance and is used at this stage in the framework of pilot projects, which develops a significant potential for its further development, taking into account the numerous advantages of the latter;

- in the parametric (index) scheme, agricultural risks were insured in the context of weather and yield index insurance products, dominant among which are weather index insurance products. Given the innovative nature of this insurance scheme in Ukrainian insurance practice, its achievements in the domestic agricultural insurance market are significant.

2. According to the results of the research, the advantages and disadvantages of index insurance products are summarized, resulting in the following: transparency and exclusion of subjective approaches in the evaluation process; significant simplification of evaluation and payment process; availability for medium and small farms; speed of reimbursement. Instead, the disadvantages are outlined as follows: the lack of an individual approach to each insurance object; risk of 'basis'; undeveloped infrastructure.

3. The application features of parametric (index) insurance schemes with emphasis on the use of weather index insurance products are considered. It is determined that the parametric (index) insurance schemes work depending on some parameter (trigger) or their combination (the index can take into account and group several parameters simultaneously). Thus, insurance based on weather indices is a real leverage of weather risks, that is, factors that actually reduce the crops yield. As a result, the research considers the possibility and feasibility of applying, together with simple weather index insurance products, combined that are able to take into account and group several parameters simultaneously and, thus, minimize the impact of the combination of weather risks at the regional level.

4. The authors suggested and, in the framework of this certain research, worked out the feasibility and possibility of using the combined weather index $(\mathrm{Ci})$ - a special indicator characterizing the effect of the combination intensity of weather risks, measured by certain parameters (heat, cold $\rightarrow$ temperature; air humidification $\rightarrow$ relative humidity; drought $\rightarrow$ preIcpitation) on the grain maize yield in the determining phases of development (flowering and grain filling).

\section{Corresponding authors}

Olena Prokopchuk, PhD

Department of Finances, Banking and Insurance, Faculty of Economics and Entrepreneurship

Uman National University of Horticulture, Ukraine, Uman

Phone: +30982453895,E-mail: olena_prokopchuk@ukr.net

ORICD: https://orIcd.org/0000-0001-7405-2469

Ihor Prokopchuk, PhD

Department of Agrochemistry and Soil Science, Faculty of Agronomy

Uman National University of Horticulture, Uman, Ukraine

Phone: +30972285417,E-mail:pivotbi@ukr.net

ORCID: https://orcid.org/0000-0001-9608-6061 
Grzegorz Mentel, $P h D$

Department of Quantitative Methods, Faculty of Management

Rzeszow University of Technology, Poland

E-mail: gmentel@prz.edu.pl

ORCID: https://orCid.org/0000-0002-6371-1219

Yurii Bilan, PhD

Centre of Applied Economic Research

Tomas Bata University in Zlin, Czech Republic

Phone:+48506354648,E-mail:yuriybilan@yahoo.co.uk

ORCID: https://orcid.org/0000-0003-0268-009X

\section{References}

[1] Barnett, B. J., Barrett, C. B. and Skees J. R. (2008) "Poverty traps and index-based risk transfer products“, World Development, Vol. 36, No. 10, pp. 1766-1785. ISSN 0305-750X. DOI 10.1016/j.worlddev.2007.10.016.

[2] Barnett, B. J. and Mahul, O. (2007) "Weather index insurance for agriculture and rural areas in lower-income countries", American Journal of Agricultural Economics, Vol. 89, No. 5, pp. 1241-1247. E-ISSN 1467-8276. DOI 10.1111/j.1467-8276.2007.01091.x.

[3] Chantarat, S., Barrett, Ch. B., Mude, A. and Turvey, C. (2007) "Using Weather Index Insurance to Improve Drought Response for Famine Prevention“", American Journal of Agricultural Economics, Vol. 89, 5, pp. 1262-1268. E-ISSN 1467-8276. DOI 10.1111/j.1467-8276.2007.01094.x.

[4] Dalhaus, T., Musshoff, O. and Finger R. (2018) "Phenology Information Contributes to Reduce Temporal Basis Risk in Agricultural Weather Index Insurance“, Scientific Reports, Vol. 8, No. 1, pp. 1-10. ISSN 2045-2322. DOI 10.1038/s41598-017-18656-5.

[5] Dandekar, V. M. (1977) "Crop insurance for developing countries, Teaching and Research Forum Paper No. 10“, Agricultural Development CounIcl, New York.

[6] Grmanová, E. and Strunz, H. (2017) "Efficiency of insurance companies: Application of DEA and Tobit analyses", Journal of International Studies, Vol. 10, No. 3, pp. 250-263. E-ISSN 2306-3483, ISSN 2071-8330. DOI 10.14254/2071-8330.2017/10-3/18.

[7] Fuchs, A. and Wolff, H. (2011) "Concept and Unintended Consequences of Weather Index Insurance: The Case of Mexico“, American Journal of Agricultural Economics, Vol. 93, No. 2, pp. 505-511. E-ISSN 1467-8276. DOI 10.1093/ajae/aaq137.

[8] Gebeltová, Z., Malec, K., Maitah, M., Smutka, L., Appiah-Kubi, S. N. K., Maitah, K., Sahatqija, J. and Sirohi, J. (2020) "The impact of crop mix on decreasing soil price and soil degradation: A case study of selected regions in Czechia (2002-2019)“, Sustainability, Vol. 12, No. 2. ISSN 2071-1050. DOI 10.3390/su12020444.

[9] Halcrow, H. G. (1948) "The theory of crop insurance“, Unpublished doctoral dissertation, University of Chicago, Department of Economics, Chicago.

[10] Kocisova, K., Gavurova, B. and Kotaskova, A. (2018) "A slack-based measure of agricultural efficiency in the European Union countries", Journal of International Studies, Vol. 11, No. 1, pp. 189-200. E-ISSN 2306-3483, ISSN 2071-8330. DOI 10.14254/2071-8330.2018/11-1/14.

[11] Mahul, O. (2001) "Optimal insurance against climatic experience", American Journal of Agricultural Economics, Vol. 83, No. 3, pp. 593-604. E-ISSN 1267-8276. ISSN 00029092. DOI 10.1111/0002-9092.00180.

[12] Malyovanyi, M., Nepochatenko, O. and Nesterchuk, Y. (2018) "Conceptual Approaches to Improving the Functioning of Non-state Social Insurance Institutions in Ukraine“, Economics and Sociology, Vol. 11, No. 2, pp. 289-304. ISSN 2071-789X. DOI 10.14254/2071-789X.2018/11-2/20. 
[13] Martseniuk-Rozaronova, O. V. (2010) "State support under insurance of agricultural producers", Economy of Agroindustrial Complex, Vol. 10, pp. 91-95.

[14] MIcntosh, C., Sarris, A. and Papadopoulos, F. (2013) "Productivity, credit, risk, and the demand for weather index insurance in smallholder agriculture in Ethiopia“, Agricultural Economics., Vol. 44, No. 4-5, pp. 399-417. E-ISSN 1574-0862. DOI 10.1111/agec.12024.

[15] Morkūnas, M., Volkov, A. and Pazienza, P. (2018) "How Resistant is the Agricultural Sector? Economic Resilience Exploited“, Economics and Sociology, Vol. 11, No. 3, pp. 321-332. ISSN 2071-789X. DOI 10.14254/2071-789X.2018/11-3/19.

[16] Navrotskyi, S. A. (2012) "State and development trends of agricultural insurance", Science and Economics, Vol. 1, No. 25, pp. 61-68.

[17] Nesterchuk, Y., Prokopchuk, O., Tsymbalyuk, Y., Rolinskyi, O. and Bilan, Y. (2018) "Current status and prospects of development of the system of agricultural insurance in Ukraine", Investment Management and FinanIcal Innovations", Vol. 15, No. 3, pp. 56-70. ISSN 1810-4967. DOI 10.21511/imfi.15(3).2018.05.

[18] Odening, M. and Shen, Z. (2014) "Challenges of insuring weather risk in agriculture", Agricultural Finance Review, Vol. 74, No. 2. ISSN 0002-1466. DOI 10.1108/AFR-11-2013-0039.

[19] Osgood, D. E., McLaurin, M., Carriquiry, M., Mishra, A., Fiondella, F., Hansen, J., Peterson, N. and Ward, N. (2007) "Designing weather insurance contracts for farmers in Malawi, Tanzania and Kenya“, International Research Institute for Climate and SoIcety, Earth Institute, Columbia University Pallisades, New York.

[20] Pointer, L. and Khoi, P. D. (2019) "Predictors of Return on Assets and Return on Equity for Banking and Insurance Companies on Vietnam Stock Exchange“, Entrepreneurial Business and Economics Review, Vol. 7, No. 4, pp. 185-198. E-ISSN 2353-8821, ISSN 2353-883X. DOI 10.15678/EBER.2019.070411.

[21] Polchanov, A. Y. (2013) "Agricultural insurance as a component of state food security", Bulletin of the Cherkasy Bohdan Khmelnytsky National University.of Trade and Economics, Vol. 4, pp. 48-57. ISSN: 2707-5044.

[22] Prokopchuk, O., Prokopchuk, I. and Mentel, G. (2018) "Index Insurance as an Innovative Tool for Managing Weather Risks in the Agrarian Sector of Economics", Journal of Competitiveness, Vol. 10, No. 3, pp. 119-131. E-ISSN 1804-1728. ISSN 1804-171X. DOI 10.7441/joc.2018.03.08.

[23] Prokopchuk, O., Nesterchuk, Y., Tsymbalyuk, Y. and Rolinskyi, O. (2019) "Current trends in agricultural insurance market operation in Ukraine", Problems and Perspectives in Management, Vol. 17, No. 3, pp. 57-75. E-ISSN 1810-5467. DOI 10.21511/ppm.17(3).2019.05.

[24] Santeramo, F. G. (2018) "Imperfect information and partiIcpation in insurance markets: evidence from Italy“, Agricultural Finance Review, Vol. 78, No. 2, pp. 193-194. ISSN 0002-1466. DOI 10.1108/AFR-06-2017-0053.

[25] Sarris, A. (2013) "Weather index insurance for agricultural development: Introduction and overview", Agricultural Economics, Vol. 44, No. 4-5, pp. 381-384. E-ISSN 1574-0862. DOI 10.1111/agec. 12022.

[26] Skees, J. R., Hazell, P. B. R. and Miranda, M. (1999) "New approaches to crop yield insurance in developing countries", International Food Policy Research Institute, Environment and Production Technology Division. EPTD discussion paper No.55. Washington, DC.

[27] Skees, J., Gober, S., Varangis, P., Lester, R. and Kalavakonda, V. (2001) "Developing RainfallBased Index Insurance in Morocco“, Working Paper No. 2577, The World Bank, Policy Research: Washington, DC.

[28] Tadesse, M. A., Shiferaw, B. and Erenstein, O. (2015) "Weather index insurance for managing drought risk in smallholder agriculture: lessons and policy implications for sub-Saharan Africa“, Agricultural and Food Economics, Vol. 3, No. 1. E-ISSN 2193-7532. DOI 10.1186/s40100-015-0044-3. 
[29] Turvey, C. G. (2001) "Weather derivatives for speIcfic event risks in agriculture", Review of Agricultural Economics. Vol. 23, No. 2, pp. 333-351. E-ISSN 1467-9353, ISSN 1058-7195. DOI 10.1111/1467-9353.00065.

[30] Ulianych, Y. V., Prokopchuk, O. T.,and Bechko, V. P. (2014) "Peculiarities of agrarian risk insurance in the countries of the world“, Actual Problems of the Economy, Vol. 3, No. 153, pp. 46-53. ISSN 19936788.

[31] Walewicz, P. (2018) "'Greening' the critical theory of international relations with the concept of world-ecology“, Toruńskie Studia Międzynarodowe, Vol. 1, No. 11, pp. 125-134. ISSN 1689-8168. DOI 10.12775/TIS.2018.011.

[32] Weber, R., Fecke, W., Moeller, I. and Musshoff, O. (2015) "Meso-level weather index insurance“, Agricultural Finance Review, Vol. 75, No. 1, pp. 31-46. ISSN 0002-1466. DOI 10.1108/AFR-12-2014-0045. 